\title{
Efficient In Vitro Callus Induction and Plant Regeneration Protocol for Different Polish Tomato Cultivars
}

\author{
Aneta GERSZBERG*, Katarzyna HNATUSZKO-KONKA, \\ Tomasz KOWALCZYK, Andrzej K. KONONOWICZ
}

\author{
University of Lodz, Department of Genetics, Plant Molecular Biology and Biotechnology, Banacha Street 12/16, 90-237 Lodz, Poland; \\ angersz@biol.uni.lodz.pl (*orresponding author); kath@biol.uni.lodz.pl; tkowal@biol.uni.lodz.pl; akononow@biol.uni.lodz.pl
}

\begin{abstract}
The major goal of this research was to establish a stable regeneration system for tomato cultivars in order to lay the foundations for the future genetic transformation of the tomato. The regeneration ability of two kinds of explants (cotyledons and hypocotyl segments) was compared for three Polish cultivars of the tomato (Solanum lycopersicum). Explants were cultured on 10 different regeneration media (basal mediums MS or B5, and with a combination of 6-benzylaminopurine (BAP) and indole-3-acetic acid (IAA). It was found that the ability to regenerate was substantially dependent on the cultivars, as well as on the kind of explant. The best explants for inducing shoot regeneration were cotyledons, followed by hypocotyls. It was noticed that the best formulation of the medium for this regeneration from the two types of explants used in this study, is MS with $2 \mathrm{mg} / \mathrm{L} \mathrm{BA}$ and $0.1 \mathrm{mg} / \mathrm{L}$ IAA. Tomato shoots were transferred to a $1 \frac{1}{2} \mathrm{MS}$ medium and $1 / 2 \mathrm{MS}$ complemented with $0.1 \mathrm{mg} / \mathrm{L}$ IAA for rooting and all of them responded positively to the rooting medium.
\end{abstract}

Keywords: Solanum lycopersicum, in vitro culture, BAP, IAA, regeneration

Abbreviations: B5-Gamborg medium; BAP-6-benzylaminopurine; 2,4-D-2,4-dichlorophenoxyacetic acid; IAA-indole-3acetic acid; IBA-indole-3-butrytic acid; 2iP-isopentenyl adenine; KIN-kinetin; MS-Murashige and Skoog medium; NAA- $\alpha$ naphthaleneacetic acid; PGRs-plant growth regulators; RGIM-root growth inducing medium; SE- standard error; SRMshoots regeneration medium.

\section{Introduction}

The tomato (Solanum lycopersicum, $2 n=2 x=24$ ), is an economically significant crop species in the entire world. Furthermore, this vegetable appears as a model plant for the introgression of agronomically crucial genes into the genome of dicotyledonous crop plants (Bhatia et al., 2004). Solanum lycopersicum has great potential for transgenic application. The introduction of qualitative traits into commercial tomato cultivars is substantial, the aim being to ameliorate its nutritional value, productivity, resistance to environmental stresses and application in molecular farming (Gerszberg et al., 2015b). This crop species exhibited extraordinary nutritional value that why it is considered to be preventive food (Raiola et al., 2014). Recently, this crop has gained huge popularity due to its anti-cancer and antioxidant characteristic (Khuong et al., 2013). Traditional methods for tomato breeding can be expensive and tedious due to the time and facilities required by each breeding generation and to the problems with the selection of suitable standards for cultivating. Therefore, as an alternative, the creation of effective regeneration protocols is an essential step for exploiting of tissue or cell culture for genetic amelioration (engineered plants for commercial uses). Elaboration of the aforementioned system is essential for positive results in a broad range of techniques, including micropropagation, mutation selection, somatic hybridization or germplasm preservation (Benson, 2000). Numerous studies pointed out that the process of tomato regeneration via the organogenesis pathway is influenced by various elements, including media composition and environmental conditions as well as genotype, explant origin and its age (Ishag et al., 2009; Rashid and Bal, 2010; Zhang et al., 2012; Wayase and Shitole, 2014). So far, several procedures were developed concerning in vitro tomato plants regeneration from diverse explants through 
organogenesis and tomato transformation (Gerszberg et al., 2015b). These findings pointed out the intractability of $S$. lycopersicum explants (fragmentary or even complete incapability to react to in vitro culture impulses) (Bhatia et al., 2004). Consequently, the improvement of a suitable recovery system exploiting tissue culture techniques of $S$. lycopersicum plants has a great meaning if we consider the fact that various genotypes differ with regards to their morphogenic potential.

The current research was focused on the impact of different media formulation on the regeneration of three Polish tomato cultivars ('Lubań', 'Malinowy Warszawski' and 'Rumba Ożarowska'). All cultivars investigated in the present study are popular and cultivated in Poland. To our knowledge there have been no notifications related to testing in vitro regeneration potential of two types of explants (hypocotyls and cotyledons) of these cultivars. Moreover, protocols are available for tomato regeneration, concerning mainly cv. Micro-Tom, or local varieties. Presented study is a prerequisite for further work concerning genetic transformation of aforementioned cultivars. The assessment of different media formulation as well as regeneration potential of two type of explants (hypocotyls and cotyledons) allowed choosing the best of explant and medium for regeneration putative tomato transformants in the next step of future experiments.

\section{Materials and Methods}

\section{Plantmaterial}

Three commercial varieties of tomato (Solanum lycopresicum L.), namely 'Lubań', 'Malinowy Warszawski' and 'Rumba Ożarowska', were purchased from PlantiCo Ltd. (Zielonki, Poland). The seeds of these varieties were surface sterilized in $70 \%(\mathrm{v} / \mathrm{v})$ ethanol for 1 minute; subsequently they were dipped in a 30\% solution of commercial bleach containing $5.5 \%(\mathrm{w} / \mathrm{v})$ of sodium hypochlorite for 10 minutes. Next, they were washed in sterile distilled water $(5$ times for 3 minutes).

\section{Culture conditions}

Prepared in this manner, seeds were placed on Petri dishes on a basal $1 / 2 \mathrm{MS}$ medium ( $\mathrm{pH} 5.8,0.8 \%$ agar and $1 \%$ sucrose) (Murashige and Skoog, 1962). Seeds germination index of cultivars achieved $\sim 90 \%$. The explants, both cotyledon and hypocotyl, were sterilely taken from seedlings ( 8 day-old) and placed on two type of media: MS or B5 (Gamborg et al., 1968) solid shoot regeneration media (SRM, 1\% sucrose and $0.8 \%$ agar, $\mathrm{pH}$ 5.8) complemented with hormones of different concentrations (Table 1).

For all media used, $\mathrm{pH}$ was determined before autoclaving. Cultures were kept in a culture room under controlled conditions at $23{ }^{\circ} \mathrm{C}\left(+/-2{ }^{\circ} \mathrm{C}\right)$ under a $16 / 8 \mathrm{~h}$ light/dark photoperiod regime (3000 lux, approx.). Subcultures were maintained at regular time periods (30 days). Experimental data were collected every 30 days. All the regeneration parameters (e.g. initiation processes or growth features) were evaluated constantly.

Explants of the three varieties were grown on 10 different media to evaluate their regeneration capability. In the experiments were used 360 explants (one series - 120 explants; one treatment - 12 explants (hypocotyls + cotyledons)). The experiments were repeated 3 times for each treatment.

After 30 days of culture on the SRM, regenerated shoots $(\sim 1.5 \mathrm{~cm}$ length) were transferred onto the root growthinducing medium (RGIM, $1 / 2 \mathrm{MS}+0$ and $0.1 \mathrm{mg} / \mathrm{LIAA}$ ) for root production and hardening. Healthy plantlets were moved to pots with a mixture of soil and perlite (3:1).

The frequency of shoot regeneration was evaluated for cotyledons and hypocotyls that had been cultured for 30 days, as described in our previous work (Gerszberg et al., 2015a).

\section{Statistical analysis}

For the analysis of the collected data one-way analysis of variance (ANOVA) was used. The data were showed as means $( \pm S E)$ which were compared by Tukey's test $(\mathrm{p}<0.05)$.

\section{Results and Discussion}

The seeds of all the $S$. esculentum cultivars were germinated on a $1 / 2$ MS medium (hormone-free). After 8 days, the germination index was $100 \%$ for cv. 'Lubań' and 'Rumba Ożarowska', and 98\% - 'Malinowy Warszawski'). These findings correspond with another research where a $1 / 2 \mathrm{MS}$ medium was used for in vitro seed germination of different tomato cultivars (Ishag et al., 2009; Ashakiran et al., 2011; Wayase and Shitole, 2014). After 8 days of germination, the seedlings had reached a height of about $3-4 \mathrm{~cm}$.

Plant growth regulators (PGRs), or phytohormones, have influenced the morphogenic response by modifying various physiological processes. In the case of tomato regeneration, a broad range of different phytohormones (eg. BAP, zeatin, 2iP (isopentenyl adenine), KIN (Kinetin), IAA, NAA ( $\alpha$ Naphthaleneacetic acid) IBA (Indole-3-butyric acid), 2,4-D (2,4-Dichlorophenoxyacetic acid) at varying concentrations have been used so far (Koleva Gudeva and Dedejski, 2012; Jehan and Hassanein, 2013; Koul et al., 2014). Moreover, the sort and concentration of PGRs used in the medium proven to be dependent on the cultivar being cultured and especially on the auxin or cytokinins utilized (Koleva Gudeva and Dedejski, 2012; Bahurupe et al., 2013; Jehan and Hassanein, 2013; Koul et al., 2014; Wayase and Shitole 2014). Induction of the regeneration process exploiting different explants cultured in vitro is the base for the majority of in vitro methods. Various types of explants were used by others: seed-cut cotyledon,

Table 1. Composition of culture media used for callus induction and plant regeneration of tomato

\begin{tabular}{cc}
\hline Medium code & Composition \\
\hline $\mathrm{MS}_{1}$ & without phytohormones \\
$\mathrm{MS}_{2}$ & $1 \mathrm{mg} / \mathrm{L} \mathrm{BAP}$ \\
$\mathrm{MS}_{3}$ & $0.5 \mathrm{mg} / \mathrm{L} \mathrm{BAP}+0.1 \mathrm{mg} / \mathrm{L} \mathrm{IAA}$ \\
$\mathrm{MS}_{4}$ & $1 \mathrm{mg} / \mathrm{L} \mathrm{BAP}+0.1 \mathrm{mg} / \mathrm{L} \mathrm{IAA}$ \\
$\mathrm{MS}_{5}$ & $2 \mathrm{mg} / \mathrm{L} \mathrm{BAP}+0.1 \mathrm{mg} / \mathrm{L} \mathrm{IAA}$ \\
$\mathrm{B}_{1}$ & without phytohormones \\
$\mathrm{B} 5_{2}$ & $1 \mathrm{mg} / \mathrm{L} \mathrm{BAP}$ \\
$\mathrm{B}_{3}$ & $0.5 \mathrm{mg} / \mathrm{L} \mathrm{BAP}+0.1 \mathrm{mg} / \mathrm{L} \mathrm{IAA}$ \\
$\mathrm{B} 5_{4}$ & $1 \mathrm{mg} / \mathrm{L} \mathrm{BAP}+0.1 \mathrm{mg} / \mathrm{L} \mathrm{IAA}$ \\
$\mathrm{B} 5_{5}$ & $2 \mathrm{mg} / \mathrm{L} \mathrm{BAP}+0.1 \mathrm{mg} / \mathrm{L} \mathrm{IAA}$ \\
\hline
\end{tabular}


454

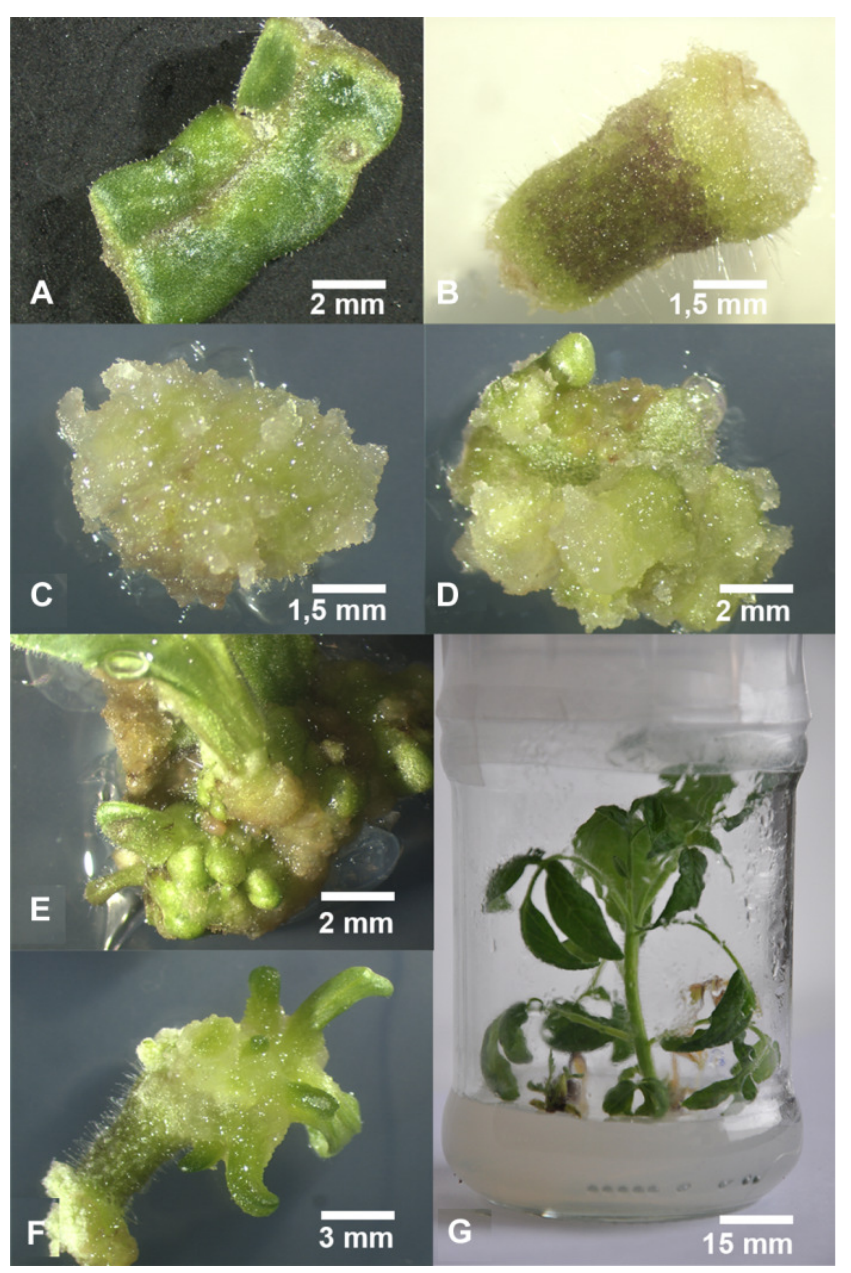

Fig. 1. Plant regeneration form hypocotyls and cotyledons Solanum lycopersicum. A, B swollen explants (respectively: cotyledon, hypocotyl); C, D differentiating callus tissue; E, F shoots proliferation; $\mathrm{G}$ regenerated plantlets

hypocotyl, leaf, stem sections, nods, internodes, pedicels, petioles, apical meristem, shoot apex/tip and inflorescences for organogenesis (ref. Gerszberg et al., 2015b). In the discussed experiment, the capability of two sorts of tomato explants (hypocotyls and cotyledons) for the regeneration through indirect organogenesis was tested. Both explants cut from tomato seedlings ( 8 day-old) were cultured on various media: MS, B5 and MS (or B5) including only BAP or BAP (at different concentrations) together with IAA for the production of callus and multiple shoots (Fig. 1 E, F).

In general, callus induction was noticed in the aforementioned type of explant culture (Fig. 1 C, D). Among the 10 media tested, no substantial variation was observed in the frequency of callus induction, with the exception of basal medium MS and B5 (Table 2).

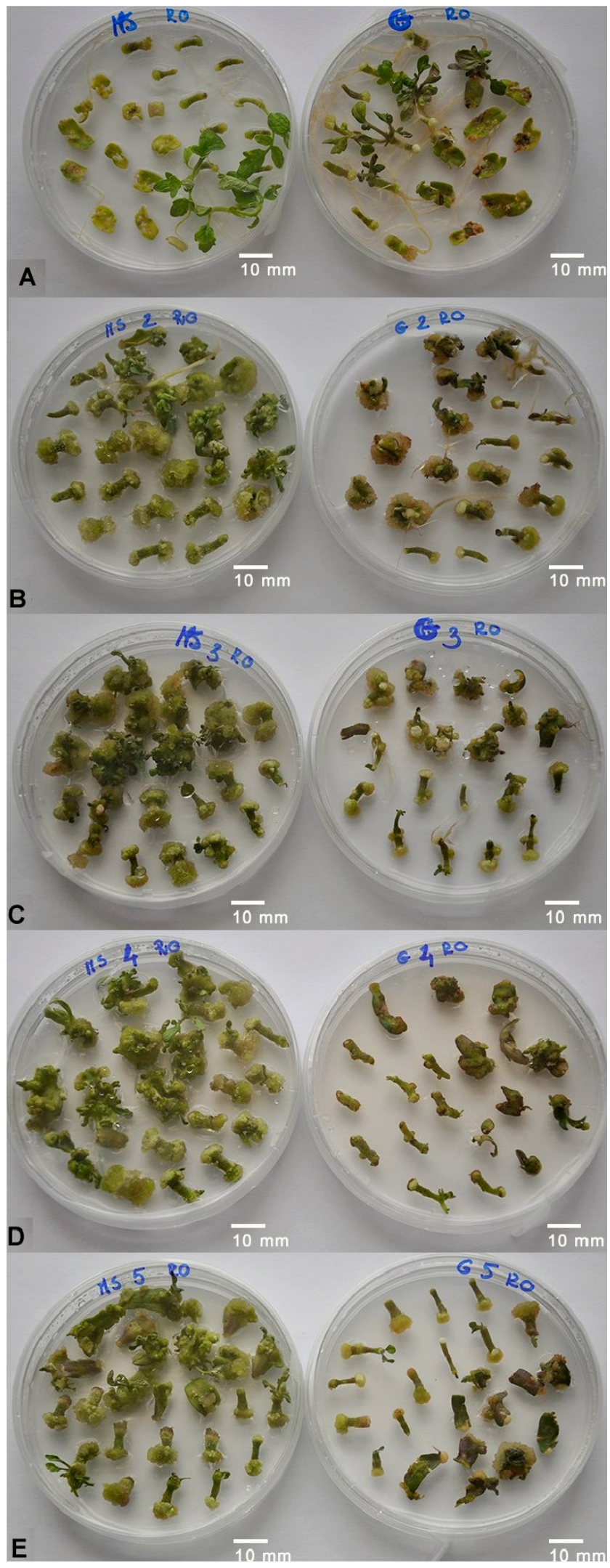

Fig. 2. Responses of S. lycopersicum cv. 'Rumba Ożarowska' explants on different variants of MS and B5 media. A - differentiating callus tissue on $\mathrm{MS}_{1}$ medium (left), $\mathrm{B} 5_{1}$ medium (right); $\mathrm{B}-\mathrm{MS}_{2}$ medium (left), $\mathrm{B} 5_{2}$ medium (right); $\mathrm{C}-\mathrm{MS}_{3}$ medium (left), $\mathrm{B}_{3}$ medium (right); $\mathrm{D}-\mathrm{MS}_{4}$ medium (left), $\mathrm{B}_{4}$ medium (right); $\mathrm{E}-\mathrm{MS}_{5}$ medium (left), $\mathrm{B} 5_{5}$ medium (right). 
However, it has been found that hypocotyls produced much more callus than cotyledons. Moreover, it was noticed that even though more calli were produced by hypocotyls, their regeneration ability was lower than that produced by cotyledons (Table 3). These results are coherent with the findings of former investigations (Ali et al., 2012). Comparing the variants of MS medium and B5 it was found that an abundant mass of callus was induced on MS media (Fig. 2).

A significant increment of callus proliferation was observed over the culture period. Swelling explants were observed within 1 week (Fig. 1 A, B). Callus formation began within $\sim 12$ days and shortly thereafter buds occurred (Fig. 1 D, E, F). The origination of calli and shoots was noticed in the middle part of explants and on cut edges. In terms of morphology, the callus was fragile and characterized by a pale yellow or green color (Fig. 1 C, D).

In general, callus originating from cotyledons revealed a higher shoot regeneration frequency in comparison to the one stemming from hypocotyl. Shoot regeneration frequency changed with medium composition, the variety and also explant type (Table 3).

Regeneration from hypocotyls occurred on all culture media. Interestingly, in the case of cotyledons cultured on both MS and B5 media without fitohormones, no response was observed and the hypocotyl response was very low (Table 3 ). Despite the fact the plant regeneration could be caused with BA only, combining with IAA enhanced the frequency of plant regeneration significantly. Moreover, the kind of elementary medium (e.g. B5 or MS) used may have a marked effect on the regeneration process rate (Ashakiran et al., 2011; $\mathrm{Wu}$ et al., 2011). According to our findings, the best formulation of the medium for regeneration from the two types of explants used in this study is MS with $2 \mathrm{mg} / \mathrm{L} \mathrm{BA}$ and $0.1 \mathrm{mg} / \mathrm{L}$ IAA. The data displayed- the highest regeneration frequency (100\%) for shoots in 'Malinowy Warszawski' and 'Lubań' cultivars. Slightly lower values were recorded for 'Rumba Ożarowska' (Table 3). This results were also reflected in the total number of regenerants obtained ( 70 for 'Malinowy Warszawski', 62 for 'Lubań' and 55 for 'Rumba Ożarowska').

These findings are consistent with the results for 'Punjab Upma' and 'IPA-3' genotypes (Rashid and Bal, 2010). However, contrastingly to our findings, Wu et al. (2011) reported that in terms of plantlet regeneration, the B5 basic medium is better than MS. It was noticed that the highest average number of shoots per one explant (3.0) of 'Rumba Ożarowska' was obtained in MS+1 mg/L BA+0.1 mg/L IAA followed by $\mathrm{MS}+2 \mathrm{mg} / \mathrm{L}$ BA+0.1 mg/L IAA (2.55). Exploiting the same medium for 'Malinowy Warszawski', the highest average value was 2.33, and for 'Luban' 2.0. It can be concluded that this medium is the best for shoot/bud induction.

Cotyledons and hypocotyls are the most exploited explants for regeneration in vitro, not only in the case of the tomato. There are several studies indicating that these explants could induce callus as well as adventitious shoots (Zhang and Bhalla, 2004; Chaudhry et al., 2010; Ali et al., 2012). Our findings are consistent with these conclusions.

We also observed that a subtype of hypocotyls explant (the individual pieces depending on of hypocotyls section) did not reveal any disparities in tomato shoot regeneration capability (data not included). These results are in agreement with data of Zhang and Bhalla (2004) on B. napus and with our previous study on B. oleracea var. capitata (Gerszberg et al., 2015a). Another study pointed out that the part of cotyledon used affects the morphogenesis process (Zhang et al., 2012). In our experiments, the middle and end part of cotyledons were employed. As a result, we obtained a high shoot regeneration response (Table 4). These findings are consistent with the data of Zhang and Bhalla (2004). Generally, the regeneration process in plants is dependent not only on the type of explants, but also on their age. It was also revealed that younger explants have been observed to provide better results in comparison to older explants (Bhatia et al., 2004). Therefore, in this study young explants from 8-day-old seedlings were utilized. However, some data indicates that the regeneration potential of tomato explants is positively correlated with increasing the age of different explants (Dai et al., 1988). Considering the sort of explant, researchers use seedlings of a broad range of age (Ishag et al., 2009; Yasmeen, 2009; Ali et al., 2012; Khuong et al., 2013). The appropriate size of explant is crucial for achieving effective recovery in tomato plants. The most favorable size for a tomato is a $5 \mathrm{~mm} \times 5 \mathrm{~mm}$ one for cotyledons and a 0.7-2 cm long section for hypocotyls (Ishag et al., 2009; Chaudhry et al., 2010). In the current study explants of these sizes were used.

Rooting is a crucial step to establish the regeneration system in plant tissue culture. This process is affected by several agents (e.g. physiological condition of recovery plantlets, sort of medium, as well as phytohormones). It has been speculated that root formation in tomatoes does not demand any exogenous PGRs (Rashid and Bal, 2010; Bahurupe et al.,

Table 2. Comparison of callus induction (\%) on different culture media* in three S. lycopersicum cultivars with no distinction of impact of explant types

\begin{tabular}{|c|c|c|c|c|}
\hline \multirow{2}{*}{ Medium } & \multicolumn{3}{|c|}{ Cultivars } & \multirow{2}{*}{ Mean } \\
\hline & 'Rumba Ożarowska' & 'Malinowy Warszawski' & 'Lubań' & \\
\hline $\mathrm{MS}_{1}$ & $41.6 \mathrm{a}$ & $38.8 \mathrm{a}$ & $44.4 \mathrm{a}$ & 41.60 \\
\hline $\mathrm{MS}_{2}$ & 88.8 bcde & 88.8 bcde & 94.4 bcde & 90.66 \\
\hline $\mathrm{MS}_{3}$ & $100.0 \mathrm{cfg}$ & $97.2 \mathrm{cfg}$ & $100.0 \mathrm{cfg}$ & 99.06 \\
\hline $\mathrm{MS}_{4}$ & $100.0 \mathrm{dfh}$ & $100.0 \mathrm{dfh}$ & $100.0 \mathrm{dfh}$ & 100.00 \\
\hline $\mathrm{MS}_{5}$ & $100.0 \mathrm{egh}$ & $100.0 \mathrm{fgh}$ & $97.2 \mathrm{fgh}$ & 99.06 \\
\hline Mean & 86.08 & 84.96 & 87.2 & 86.08 \\
\hline $\mathrm{B} 55_{1}$ & $47.7 \mathrm{a}$ & $44.4 \mathrm{a}$ & $47.2 \mathrm{a}$ & 46.43 \\
\hline $\mathrm{B} 5{ }_{2}$ & $86.1 \mathrm{bcde}$ & 83.3 bcde & 88.8 bcde & 86.06 \\
\hline $\mathrm{B} 5_{3}$ & $100.0 \mathrm{cfg}$ & $91.6 \mathrm{cfg}$ & $100.0 \mathrm{cfg}$ & 97.20 \\
\hline$B 5_{4}$ & $100.0 \mathrm{dfh}$ & $100.0 \mathrm{dfh}$ & $100.0 \mathrm{dfh}$ & 100.00 \\
\hline $\mathrm{B} 5_{5}$ & $100.0 \mathrm{egh}$ & $100.0 \mathrm{fgh}$ & $100.0 \mathrm{fgh}$ & 100.00 \\
\hline Mean & 86.76 & 83.86 & 87.2 & 85.94 \\
\hline
\end{tabular}


456

Table 3. Effects of culture media and explant type on shoot regeneration* in three S. lycopersicum cultivars

\begin{tabular}{|c|c|c|c|c|}
\hline \multirow{2}{*}{$\begin{array}{c}\text { Medium variant/ } \\
\text { 'Rumba Ożarowska' cv. }\end{array}$} & \multicolumn{2}{|c|}{ Percentage of explants with shoots } & \multicolumn{2}{|c|}{ Mean No. of shoots/buds per explants } \\
\hline & Cotyledon & Hypocotyl & Cotyledon & Hypocotyl \\
\hline $\mathrm{MS}_{1}$ & $0.0 \mathrm{a}$ & $38.8 \mathrm{a}$ & $0.0 \mathrm{a}$ & $0.38 \pm 0.12 \mathrm{a}$ \\
\hline $\mathrm{MS}_{2}$ & 72.2 bce & $50.0 \mathrm{a}$ & $1.55 \pm 0.27 \mathrm{abcd}$ & $0.55 \pm 0.15 \mathrm{a}$ \\
\hline $\mathrm{MS}_{3}$ & $94.4 \mathrm{bd}$ & $50.0 \mathrm{a}$ & $3.00 \pm 0.24 \mathrm{be}$ & $0.61 \pm 0.14 \mathrm{a}$ \\
\hline $\mathrm{MS}_{4}$ & $83.3 \mathrm{~cd}$ & $77.7 \mathrm{ab}$ & $2.55 \pm 0.32 \mathrm{cef}$ & $1.22 \pm 0.24 \mathrm{a}$ \\
\hline $\mathrm{MS}_{5}$ & $77.7 \mathrm{e}$ & $27.7 \mathrm{ac}$ & $0.83 \pm 0.35 \mathrm{adf}$ & $0.44 \pm 0.23 \mathrm{a}$ \\
\hline $\mathrm{B} 5{ }_{1}$ & $0.0 \mathrm{a}$ & $33.3 \mathrm{ab}$ & $0.0 \mathrm{a}$ & $0.44 \pm 0.20 \mathrm{a}$ \\
\hline $\mathrm{B}_{2}$ & 55.5 bcde & $44.4 \mathrm{a}$ & $0.83 \pm 0.28 \mathrm{a}$ & $0.61 \pm 0.14 \mathrm{a}$ \\
\hline $\mathrm{B}_{3}$ & $55.5 \mathrm{cde}$ & $83.3 \mathrm{ac}$ & $1.0 \pm 0.28 \mathrm{acd}$ & $2.22 \pm 0.22 \mathrm{bc}$ \\
\hline B5 4 & $77.7 \mathrm{~d}$ & $50.0 \mathrm{a}$ & $2.0 \pm 0.29 \mathrm{bc}$ & $1.11 \pm 0.30 \mathrm{ac}$ \\
\hline $\mathrm{B} 55_{5}$ & $50.0 \mathrm{e}$ & $38.8 \mathrm{a}$ & $0.5 \pm 0.25 \mathrm{ad}$ & $0.38 \pm 0.14 \mathrm{a}$ \\
\hline Medium variant/ & \multicolumn{2}{|c|}{ Percentage of explants with shoots } & \multicolumn{2}{|c|}{ Mean No. of shoots/buds per explants } \\
\hline 'Malinowy Warszawski' cv. & Cotyledon & Hypocotyl & Cotyledon & Hypocotyl \\
\hline $\mathrm{MS}_{1}$ & $0.0 \mathrm{a}$ & $66.6 \mathrm{a}$ & $0.0 \mathrm{a}$ & $0.72 \pm 0.21 \mathrm{a}$ \\
\hline $\mathrm{MS}_{2}$ & 77.0 bde & $77.7 \mathrm{a}$ & $0.77 \pm 0.13$ bce & $1.0 \pm 0.16 \mathrm{a}$ \\
\hline $\mathrm{MS}_{3}$ & $94.4 \mathrm{cb}$ & $83.3 \mathrm{ab}$ & $1.11 \pm 0.11 \mathrm{cf}$ & $1.5 \pm 0.19 \mathrm{a}$ \\
\hline $\mathrm{MS}_{4}$ & $100 \mathrm{dc}$ & $100 \mathrm{ae}$ & $2.33 \pm 0.16 \mathrm{~d}$ & $1.44 \pm 0.18 \mathrm{a}$ \\
\hline $\mathrm{MS}_{5}$ & $61.1 \mathrm{e}$ & $44.4 \mathrm{acf}$ & $1.0 \pm 0.24 \mathrm{ef}$ & $0.44 \pm 0.18 \mathrm{a}$ \\
\hline $\mathrm{B} 5{ }_{1}$ & $0.0 \mathrm{a}$ & $50.0 \mathrm{a}$ & $0.0 \mathrm{a}$ & $0.61 \pm 0.22 \mathrm{a}$ \\
\hline $\mathrm{B} 5_{2}$ & $61.1 \mathrm{bcde}$ & $55.5 \mathrm{a}$ & $0.83 \pm 0.23 \mathrm{abd}$ & $0.71 \pm 0.21 \mathrm{a}$ \\
\hline $\mathrm{B} 5{ }_{3}$ & $77.7 \mathrm{cfg}$ & $66.6 \mathrm{a}$ & $1.0 \pm 0.26$ be & $1.11 \pm 0.21 \mathrm{ab}$ \\
\hline $\mathrm{B} 54$ & $88.8 \mathrm{df}$ & $88.8 \mathrm{ab}$ & $2.0 \pm 0.23 c$ & $1.22 \pm 0.21 \mathrm{adf}$ \\
\hline $\mathrm{B} 55_{5}$ & $50.0 \mathrm{eg}$ & $33.3 \mathrm{ac}$ & $0.5 \pm 0.19$ ade & $0.33 \pm 0.14$ ace \\
\hline \multirow{2}{*}{$\begin{array}{l}\text { Medium variant/ } \\
\text { 'Lubań' cv. }\end{array}$} & \multicolumn{2}{|c|}{ Percentage of explants with shoots } & \multicolumn{2}{|c|}{ Mean No. of shoots/buds per explants } \\
\hline & Cotyledon & Hypocotyl & Cotyledon & Hypocotyl \\
\hline $\mathrm{MS}_{1}$ & $0.0 \mathrm{a}$ & $66.6 \mathrm{a}$ & $0.0 \mathrm{ab}$ & $1.0 \pm 0.18 \mathrm{a}$ \\
\hline $\mathrm{MS}_{2}$ & 88.8 bcde & 77.7 abcde & $1.11 \pm 0.25$ acde & $0.94 \pm 0.21 \mathrm{a}$ \\
\hline $\mathrm{MS}_{3}$ & $100 \mathrm{cf}$ & 100 bef & $1.61 \pm 0.23 \mathrm{cfg}$ & $1.16 \pm 0.19 \mathrm{a}$ \\
\hline $\mathrm{MS}_{4}$ & $100 \mathrm{df}$ & $100 \mathrm{cfg}$ & $2.0 \pm 0.24 \mathrm{dfh}$ & $1.5 \pm 0.23 \mathrm{a}$ \\
\hline $\mathrm{MS}_{5}$ & $77.7 \mathrm{e}$ & $72.2 \mathrm{adg}$ & $0.94 \pm 0.19$ aegh & $0.83 \pm 0.23 \mathrm{a}$ \\
\hline B5 1 & $0.0 \mathrm{a}$ & $55.5 \mathrm{ab}$ & $0.55 \pm 0.18 \mathrm{a}$ & $0.55 \pm 0.17 a$ \\
\hline $\mathrm{B} 5{ }_{2}$ & 83.3 bcde & $66.6 \mathrm{a}$ & $0.77 \pm 0.17 \mathrm{a}$ & $0.77 \pm 0.15 \mathrm{a}$ \\
\hline $\mathrm{B}_{3}$ & $88.3 \mathrm{cfg}$ & $88.8 \mathrm{a}$ & $1.11 \pm 0.21 \mathrm{a}$ & $1.0 \pm 0.14 \mathrm{a}$ \\
\hline B5 4 & $94.4 \mathrm{dfh}$ & $100 \mathrm{ad}$ & $1.2 \pm 0.21 \mathrm{a}$ & $1.2 \pm 0.22 \mathrm{a}$ \\
\hline$B 55$ & $72.2 \mathrm{egh}$ & 61.1 ace & $0.72 \pm 0.16 \mathrm{a}$ & $0.72 \pm 0.19 a$ \\
\hline
\end{tabular}

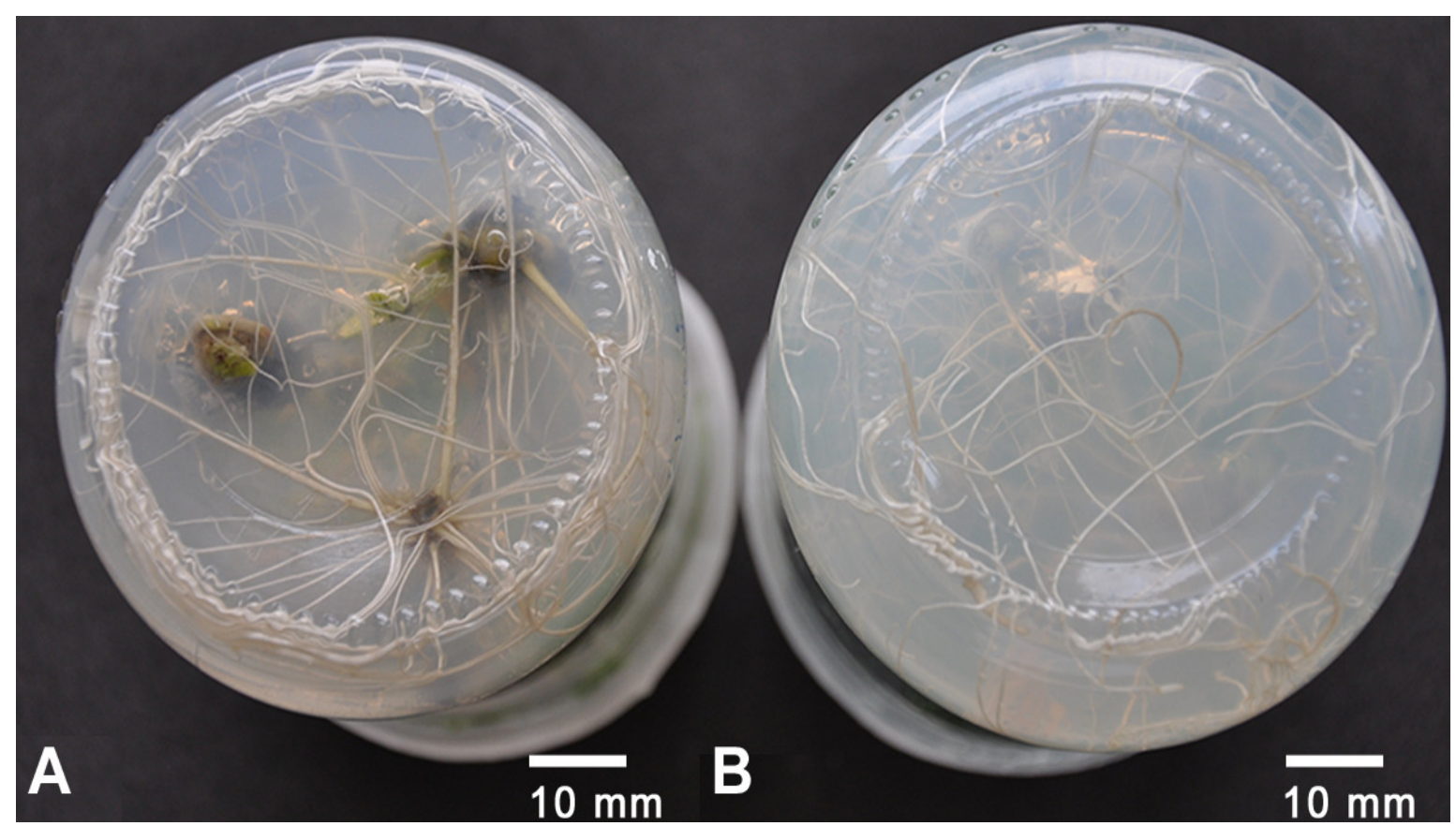

Fig. 3. Rooting on in vitro regenerated shoots in $\mathrm{A} 1 / 2 \mathrm{MS}$ and $\mathrm{B} 1 / 2 \mathrm{MS}$ supplemented with $0.1 \mathrm{mg} / \mathrm{L}$ IAA 


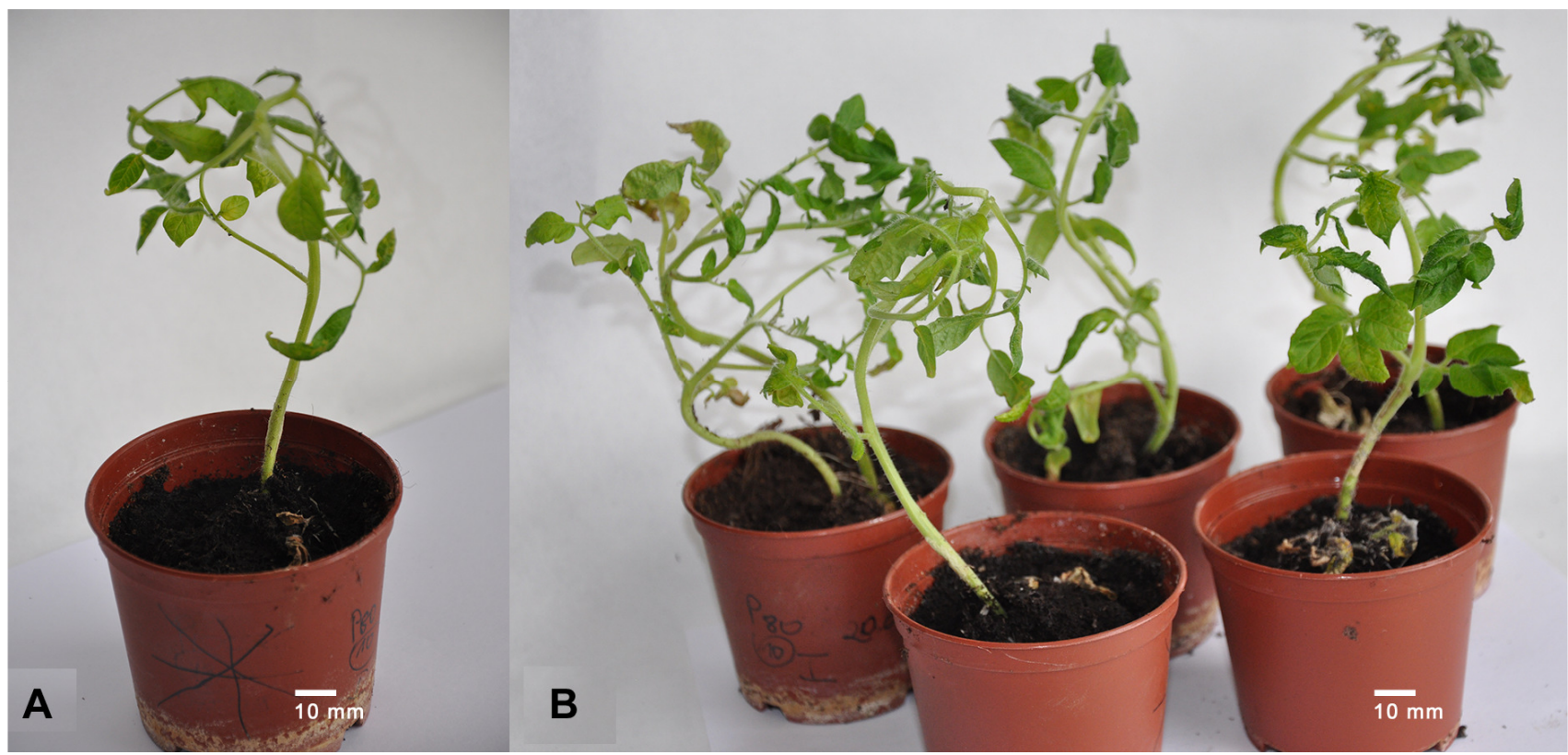

Fig. 4. A, B. Regenerated plantlets Solanum lycopersicum in plastic pots containing soil and perlite

2013). This fact is explained by a high content of endogenous auxins (Jehan and Hassanein, 2013). Nevertheless, the majority of the rooting cases would be reached exploiting exogenous auxins alone (Chaudhry et al., 2010; Ashakiran et al., 2011). Moreover it has been revealed that the kind of auxin used, has influence on the frequency of root induction (Jehan and Hassanein, 2013). In the current investigation, rooting was performed on a basal medium - $1 / 2$ MS and a $1 / 2$ MS medium supplemented with $0.1 \mathrm{mg} / \mathrm{L}$ IAA (Fig. 3A, B).

After 5-7 days all shoots were rooted regardless of the medium type. It is not surprise that the supplementation of IAA was found to be essential for the successful generation of healthy roots. After two weeks, we noticed that the medium with the addition of $-0.1 \mathrm{mg} / \mathrm{L}$ IAA was more appropriate for inducing normal and healthy roots (Fig. 3A). On a $1 / 2$ MS medium, the induction and development of roots took longer. Furthermore, they became thin and elongated with further culture duration (Fig. 3B).

Our findings suggested that $1 / 2 \mathrm{MS}$ in combination with 0.1 $\mathrm{mg} / \mathrm{L} \mathrm{IAA}$ is a more convenient medium for rooting than $1 / 2$ MS. Our data are coherent with other research results (Ishag $e t$ al., 2009; Zhang et al., 2012; Jehan and Hassanein, 2013). Plants with well-developed root system were moved to pots with a compound of soil and perlite (3:1) and subsequently successfully acclimated and grown in a glasshouse (Fig. 4 A, B). All in vitro plants were characterized by normal phenotypic appearance.

\section{Conclusions}

Summarizing, our data revealed an acceptable frequency of regeneration from two types of explants (cotyledons and hypocotyls) on multiplication media comprising MS $+1 \mathrm{mg} / \mathrm{L}$ $\mathrm{BA}+0.1 \mathrm{mg} / \mathrm{L} \mathrm{IAA}$ or $\mathrm{MS}+2 \mathrm{mg} / \mathrm{L} \mathrm{BA}+0.1 \mathrm{mg} / \mathrm{L} \mathrm{IAA}$. Callus induction was noticed in both sorts of explants. However, cotyledons appeared to be much more suitable explants for in vitro tomato plant regeneration. Development of an effective in vitro regeneration protocol for crop species could be extremely beneficial in the process of cultivating and creating new varieties or in breeding lines in a relatively short period of time and for genetic improvement by exploiting biotechnology strategies. It is known, that more than ten thousands tomato cultivars exist, and for this reason it is impossible established one universal protocol for tomato regeneration. Therefore it is fully justified to create a tissue culture protocol for chosen commercially important varieties. This step should be preceded by wide screening of morphogenic potential aforementioned varieties. Our study would provide novel valuable information concerning this highly important issue.

\section{Acknowledgements}

This work was financially supported by University of Lodz (research fund 506/041157).

\section{References}

Ali AA, Yossef TR, El-Banna A (2012). Cytokinincytokinin interaction ameliorates the callus induction and plant regeneration of tomato (Solanum lycopersicum Mill.).Acta Agronomica Hungarica 60:47-55.

Ashakiran K, Sivankalyani V, Jayanthi M, Govindasamy V, Girija S (2011). Genotype specific shoots regeneration from different explants of tomato (Solanum lycopersicum L.) using TDZ. Asian Journal of Plant Science and Research 2:107-113.

Bahurupe JV, Patil SC, Pawar BD, Chimote VP, Kale AA (2013). Callus induction and plantlet regeneration in tomato (Solanum lycopersicum L.). Journal of Cell and Tissue Research 2:3765-3768. 
458

Bhatia P, Ashwath N, Senaratna T, Midmore D (2004). Tissue culture studies of tomato (Lycopersicum esculentum). Plant Cell Tissue and Organ Culture 78:1-21.

Benson EE (2000). Special symposium: In vitro plant recalcitrance: An introduction. In Vitro Cellular \& Developmental Biology - Plant 36:141-148.

Chaudhry Z, Abbas S, Yasmin A, Rashid H, Ahmed H, Akbar Anjum M (2010). Tissue culture studies in tomato (Lycopesicon esculentum) var. Money Maker. Pakistan Journal of Botany 1:155-163.

Dai CX, Mertz D, Lambeth VN (1988). Effect of seedling age, orientation and genotype of hypocotyl and cotyledon explants of tomato on shoot and root regeneration. Genetic Manipulation in Crops Newsletter 4:26-35.

Gamborg OL, Miller RA, Ojima K (1968). Nutrient requirements of suspension cultures of soybean root cells. Experimental Cell Research 50:151-158.

Gerszberg A, Hnatuszko-Konka K, Kowalczyk T (2015a). In vitro regeneration of eight cultivars of Brassica oleracea var. capitata. In Vitro Cellular \& Developmental Biology - Plant 51:80-87.

Gerszberg A, Hnatuszko-Konka K, Kowalczyk T, Kononowicz AKK (2015b). Tomato (Solanum lycopersicum L.) in the service of biotechnology. Plant Cell Tissue and Organ Culture 120:881-902.

Ishag S, Osman MG, Khalafalla MM (2009). Effects of growth regulators and genotype on shoot regeneration in tomato (Lycopersicon esculentum cv. Omdurman). International Journal of Sustainable Crop Production 6:7-13.

Jehan S, Hassanein AM (2013). Hormonal requirements trigger different organogenic pathways on tomato nodal explants. American Journal of Plant Sciences 4:2118-2125.

Khuong TTH, Crété P, Robaglia C, Caffarri S (2013). Optimisation of tomato Micro-tom regeneration and selection on glufosinate/Basta and dependency of gene silencing on transgene copy number. Plant Cell Reports 32:1441-1454.
Koleva Gudeva L, Dedejski G (2012). In vivo and in vitro production of some genotypes of cherry tomato Solanum lycopersicum var. Cerasiforme (Dunal). International Journal of Farming and Allied Science 4:91-96.

Koul B, Srivastava S, Amla DV, Sanyal I (2014). Establishement and optimization of Agrobacteriummediated transformation and regeneration of tomato (Solanum lycopersicum L.). International Journal of Biosciences 10:51-69.

Murashige T, Skoog F (1962). A revised medium for rapid growth and bioassays with tobacco tissue cultures. Physiologia Plantarum 15:473-497.

Raiola A, Rigano MM, Calafiore R, Frusciante L, Barone A (2014). Enhancing the human-promoting effects of tomato fruit for biofortified food. Mediators of Inflammation ID 139873 , doi: $10.1155 / 2014 / 139873$.

Rashid R, Bal SS (2010). Effect of hormones on direct shoot regeneration in hypocotyl explants of tomato. Notulae Scientia Biologicae 1:70-73.

Wayase UR, Shitole MG (2014). Effect of plant growth regulators and organogenesis in tomato (Lycopersicon esculentum Mill.) cv. Dhanashri. International Journal of Pure and Applied Sciences and Technology 2:65-71.

Wu Z, Sun S, Wang F, Guo D (2011). Establishment of regeneration and transformation system of Lycopersicon esculentum Micro Tom. British Biotechnology Journal 3:53-60.

Yasmeen A (2009). An improved protocol for the regeneration and transformation of tomato (cv. Rio Grande). Acta Physiologiae Plantarum 31:12711277.

Zhang Y, Bhalla PL (2004). In vitro shoot regeneration from commercial cultivars of Australian canola (Brassica napus L.). Australian Journal of Agricultural Research 55:753-756.

Zhang W, Hou L, Zhao H, Li M (2012). Factors affecting regeneration of tomato cotyledons. Bioscience Methods 4:27-3. 